\title{
"Alegria, alegria" e "Baby": as canções síntese do movimento tropicalista
}

\author{
Vinícius André Minhoto da Costa*
}

\section{Resumo}

Em relação ao que existia em música popular na década de 1960, a proposta tropicalista mostrava-se completamente inovadora, sugerindo a criação de um outro estilo para as canções nacionais, o qual, em linhas gerais, incorporasse influências estrangeiras. Este artigo, por meio de duas canções de Caetano Veloso, defenderá que "Alegria, alegria" (Caetano Veloso, 1967) e "Baby" (Tropicália — Panis et Circencis, 1968) sintetizam de maneira precisa as características do movimento. Para isso, resgatará o contexto de criação e os objetivos do Tropicalismo, analisando posteriormente as canções mencionadas sob uma perspectiva multimodal (ROJO, 2012), considerando então não só a letra, mas também a forma como a sonoridade constrói sentido em cada uma dessas faixas. Palavras-chave: Tropicalismo. Gênero Canção. Caetano Veloso. Multiletramentos.

* Universidade Estadual de Campinas (UNICAMP). Graduado em Letras e mestrando em Linguística Aplicada pela mesma instituição. Professor da Educação Básica (Ensino Médio). 


\section{'Alegría, alegría' y 'baby': las canciones que resumen el movimiento tropicalista}

\section{Resumen}

En relación con lo que existía en la música popular en los años 60 , la propuesta tropicalista fue completamente innovadora, sugiriendo la creación de otro estilo para canciones nacionales, que, en general, incorporaba influencias extranjeras. Este artículo, a través de dos canciones de Caetano Veloso, argumentará que "Alegria, alegria" (Caetano Veloso, 1967) y "Baby" (Tropicália - Panis et Circencis, 1968) resumen con precisión las características del movimiento. Para eso, rescatará el contexto de creación y los objetivos del Tropicalismo, analizando posteriormente las mencionadas canciones desde una perspectiva multimodal (ROJO, 2012), considerando no solo la letra, sino también la forma en que el sonido construye significado en cada una de estas canciones.

Palavras clave: Tropicalismo. Género canción. Caetano Veloso. Multialfabetizaciones.

Recebido em: 21/07/2021 // Aceito em: 23/12/2021. 


\section{Introdução}

Nas preliminares da criação do movimento tropicalista, a canção brasileira da década de 1960 digeria ainda as contemplações provenientes:

- da Bossa Nova de João Gilberto, um ritmo criado no Brasil, que integrava a MPB, grupo formado por jovens de classe média e que tematizava sobretudo relações amorosas nas letras, passando pelo samba urbano, pelo jazz e pelos ritmos regionais

- e da Jovem Guarda de Roberto Carlos, influencia ao pela sonoridade norte-americana dos Beatles, formada por jovens egressos das camadas populares, com letras que abordavam namoros, carros e festas (GARSON, 2018).

A partir, porém, do histórico III Festival de Música Popular da TV Record de $1967^{1}$ e sob o pano de fundo dos anos iniciais da ditadura militar no Brasil, o tropicalismo apresentou-se como uma ressignificação do âmbito cultural. Ainda que tenha se atrelado principalmente à música, o movimento também ecoou em outras manifestações artísticas, as quais listarei posteriormente.

Em relação ao que existia em música popular na década de 60 , a proposta tropicalista mostrava-se completamente inovadora, sugerindo a criação de um outro estilo para as canções nacionais, o qual se formava por uma espécie de revisão crítica da canção brasileira:

\footnotetext{
1 Os festivais compõem etapa fundamental da história da MPB. Com o intuito de revelar intérpretes e compositores ao grande público, eram promovidos por emissoras de rádio, redes de televisão, teatros e movimentos estudantis. Jurados avaliavam os trabalhos apresentados, classificando ou desclassificando as músicas para as etapas seguintes da competição (CALIL; TERRA, 2010). Sucessos de audiência, essas iniciativas possibilitaram o surgimento de grandes nomes da canção brasileira, como Elis Regina, Chico Buarque, Milton Nascimento etc. O site GZH elaborou um guia histórico online e interativo desses festivais, que está disponível no seguinte endereço eletrônico: http://www.clicrbs.com.br/sites/swf/zh-festivais-mpb/record-67.html. Acesso em 05 jun. 2020.
} 
Pode-se dizer que o Tropicalismo realizou no Brasil a autonomia da canção, estabelecendo-a como um objeto enfim reconhecível como verdadeiramente artístico [...]. Reinterpretar Lupicínio Rodrigues, Ary Barroso, Orlando Silva, Lucho Gatica, Beatles, Roberto Carlos, Paul Anka; utilizar-se de colagens, livres associações, procedimentos pop eletrônicos, cinematográficos e de encenação; misturá-los fazendo perder a identidade, tudo fazia parte de uma experiência radical da geração dos $60[\ldots]$ O objetivo era fazer a crítica dos gêneros, estilos e, mais radicalmente, do próprio veículo e da pequena burguesia que vivia o mito da arte [...] mantiveram-se fiéis à linha evolutiva, reinventando e tematizando criticamente a canção. (NAPOLITANO; VILLAÇA, 1998).

Havia, à época, uma tensão muito marcada entre a MPB e a Jovem Guarda. A Tropicália pretendia superar esse embate, tanto quanto outros mais profundos, entre Bossa Nova e samba tradicional, ou até mesmo entre música sofisticada moderna e música comercial vulgar (VELOSO, 1997). O movimento procurava "sincretizar"2 essas vertentes da canção brasileira, compondo uma "geleia geral" na qual se misturassem também influências internacionais. Como exemplo disso, Veloso (1997) define o encontro, num festival da TV Record em 1968, entre Orlando Silva, pertencente ao grupo que começava a se chamar MPB, e Roberto Carlos, símbolo maior da Jovem Guarda, como uma emoção tropicalista.

Como já mencionado, apesar de "a maior vitrine" ter sido justamente o campo musical, Napolitano e Villaça (1998) ressaltam que o tropicalismo também influenciou e absorveu outras artes. No cinema, pode-se destacar Terra em transe, de Glauber Rocha. No teatro, $\mathbf{O}$ rei da vela e Roda Viva, peças encenadas pelo grupo Oficina. Nas artes plásticas, o trabalho de

2 "A palavra-chave para se entender o tropicalismo é sincretismo [...]" (VELOSO, 1997, p. 292). 
Hélio Oiticica de onde veio o nome do movimento ("Tropicália") foi um ambiente-labirinto, exposto no Museu de Arte Moderna do Rio de Janeiro em abril de 1967, com signos e imagens à época muito associados ao Brasil (plantas, areia, araras, poemasobjetos, capas Parangolé e aparelho de televisão), na qual uma experiência sinestésica aproveitava ideias de vanguarda para a produção de críticas sociais. Segundo o criador, quem caminhava pelo ambiente tinha a sensação de estar caminhando pelos morros cariocas (ENCICLOPÉDIA ITAÚ CULTURAL, 2020).

\section{Imagem 1 - Tropicália, de Hélio Oiticica}

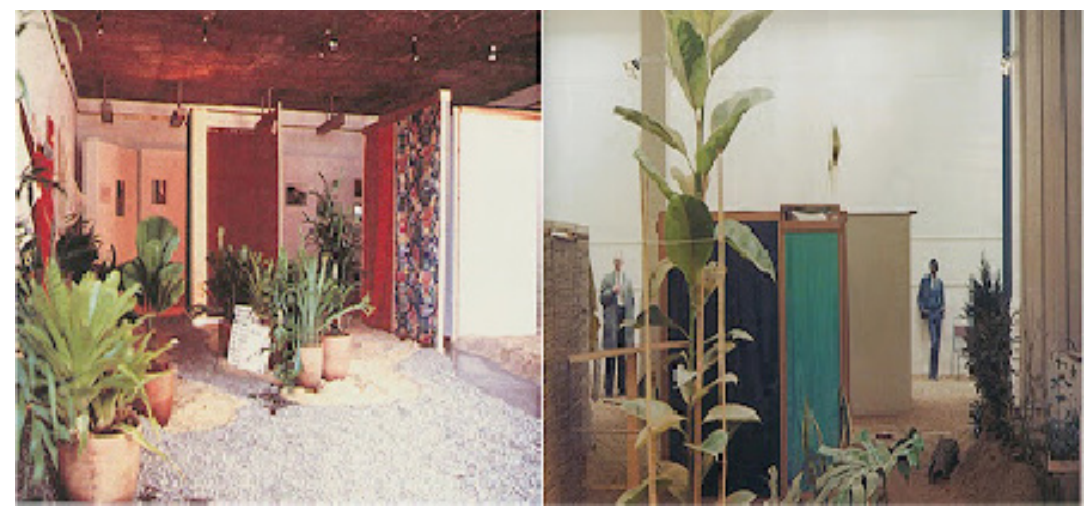

Fonte: acervo do autor.

Não posso deixar de mencionar a influência modernista no tropicalismo. A Semana de Arte Moderna, ocorrida em São Paulo em 1922, apresentou ao público obras de artistas brasileiros resultadas da influência das vanguardas europeias. Em resumo, essa iniciativa defendia que a adesão a elementos da arte estrangeira poderia colaborar positivamente com o cenário artístico nacional, reinventando-o. Anos depois, o Tropicalismo resgataria esses ideais, absorvendo o que havia de positivo na música pop de então, sem pretender copiar grosseiramente o 
que havia na arte do exterior - o que leva Napolitano e Villaça (1998) a classificarem esse gesto como revisão crítica da cultura nacional.

O III Festival de Música Popular da TV Record de 1967 é, por isso, um acontecimento central, pois, atenuado pelo clima político da época, apresentou ao público o estilo que no ano posterior seria denominado Tropicália: Caetano Veloso, acompanhado das guitarras dos roqueiros argentinos da banda Beat Boys, cantou "Alegria, alegria". Gilberto Gil, antes de entrar com a banda de rock Os mutantes para cantar "Domingo no parque", foi apresentado como "um compositor que procura dar um som universal à música brasileira [...]" (CALIL; TERRA, 2010).

A Tropicália representou um impacto na música brasileira (CHEDIAK, 1997). Dada sua dimensão, à época, mesmo as pessoas que não compactuaram com os ideais do movimento não negaram a inovação estético-comportamental que estava sendo construída (NAPOLITANO; VILLAÇA, 1998). A proposta foi recebida com bastante polêmica e colecionou apoiadores e críticos - neste último grupo, insere-se a esquerda nacionalista de então, que se opunha ao movimento, defendendo que a adesão à influência musical estrangeira seria, metaforicamente, uma redenção do imperialismo num contexto de incertezas políticas.

A importância do movimento para o cenário cultural brasileiro é tamanha que, até os dias atuais, continua sendo tematizado na grande mídia e em discussões acadêmicas, reverberando (também e ainda!) em diversas manifestações artísticas. Este artigo, por meio de duas canções de Caetano, defenderá que as canções "Alegria, alegria" e "Baby" sintetizam de maneira precisa a essência do tropicalismo. $\mathrm{O}$ artigo também 
mencionará outras canções, mas o foco estará nessas duas mencionadas. Ao longo deste texto, você, leitor(a), encontrará QR Codes para as canções de Caetano mencionadas e, ao final, também o link para acessá-las no YouTube. Isso, além de um convite para a audição delas - pois ter contato com a trilha sonora desse período histórico é fundamental para recuperar as memórias e os fatos aqui listados -, é uma lembrança de que, sobretudo na análise das canções, relacionar a letra com o aspecto musical possibilita uma leitura mais completa da canção, sem reduzi-la apenas à letra, como tipicamente é feito nas escolas e na academia.

\section{0 músico intelectual}

Caetano Emanuel Vianna Teles Veloso nasceu em Santo Amaro da Purificação(BA) em 7 de agosto de 1942. Manifestando tendências artísticas desde os 5 anos de idade, interessouse por música, pintura e desenho. Ao final da adolescência, aprendeu violão e começou a se apresentar com a irmã, Maria Bethânia, em bares de Salvador. Ingressou no curso de filosofia da Universidade Federal da Bahia, mas largou os estudos para priorizar a carreira musical. Com mais de 40 álbuns lançados, ${ }^{3}$ hoje é um dos maiores nomes da Música Popular Brasileira, estando constantemente em evidência nas rádios, emissoras de TV e redes sociais.

Entre alguns livros, escreveu Verdade Tropical, lançado pela Companhia das Letras em 1997, no qual são tematizados: autobiografia, história do tropicalismo e da MPB e ensaio de nacionalidade (JULIÃO, 2016). A respeito deste último tópico,

$\overline{3}$ VELOSO, C. Site oficial - biografia. Disponível em: http://www.caetanoveloso.com.br/biografia/. Acesso em 10 mai. 20. 
especificamente, Wisnik (2005) traça uma aproximação entre o músico e os grandes intérpretes do Brasil, como Gilberto Freyre, Sérgio Buarque de Holanda e Antonio Candido, o que, então, inseriria Caetano dentre a "grande tradição dos intérpretes da 'formação' brasileira [...]”' (WISNIK, 2015, p. 121). Esse enquadramento evidencia que as ideias apresentadas em Verdade Tropical são relevantes para se pensar o Brasil - nesse caso, sob a ótica de um músico popular. Seu principal debatedor, Schwarz $\left(2005^{4}\right.$; 2012) não deixa de ressaltar o ineditismo do fato de um músico popular ser reconhecido socialmente como um intelectual.

Portanto, sob essa perspectiva, a canção Tropicália, por exemplo, funciona como símbolo do movimento não só pelo título, mas ainda mais pela sonoridade psicodélica (na qual são utilizados efeitos eletrônicos e uma percussão misteriosa para conceder à faixa sensações sinestésicas e alucinantes), pelo conteúdo da letra e também pelo caráter poético: "Domingo é o fino-da-bossa/ Segunda-feira está na fossa [...]”. A antítese evidencia a ótica tropicalista: a de exposição e, sobretudo, aceitação de contradições hipoteticamente intrínsecas ao Brasil, estas justapostas durante toda a canção referida. Napolitano e Villaça (1998, p. 2) sugerem ainda:

Como ponto de partida, as análises devem encarar, em todas as suas contradições, o legado maior do Tropicalismo: a incorporação com intenções de crítica cultural, dos impasses e dilemas gerados pela modernização da sociedade brasileira, no universo do consumo. Ajudando a problematizar (e quando não, a confundir) a própria dicotomia entre cultura versus consumo, as relíquias do Brasil, altamente valorizadas, já podem ficar expostas nas melhores lojas; vendidas não como antiguidades exóticas, mas em meio às

$\overline{4}$ Apesar de a versão impressa utilizada neste artigo ter sido publicada em 2005, a primeira versão do mesmo texto é de 1970. 
últimas novidades do mercado (grifo dos autores).

Veloso (1997, p. 500), citando a frase de Hobsbawm que atesta que "em cultura popular no século $\mathrm{XX}$, ou se era americano ou provinciano [...]", afirma que o tropicalismo era um enfrentamento dessa questão, pois "pretendia situar-se além da esquerda [...]" (VELOSO, 1997, p. 179) e estava "livre de amarras políticas tradicionais [...]" (VELOSO, 1997, p. 319).

Conforme descrito anteriormente, à época, a esquerda nacionalista (contra a qual Caetano elaborou um revoltado discurso no Festival Internacional da Canção em 1968) não se identificou com a internacionalização cultural que o movimento propunha, o que incluía, por exemplo, o uso de guitarra elétrica e de palavras e expressões da língua inglesa nas canções da MPB (como é o caso da canção Baby, de 1968, a qual será analisada posteriormente).

Santos (2014), explica que o aspecto pop se colocava, para a massa, como um facilitador do consumo de arte, o que levaria a um aumento do público e também a uma internacionalização da cultura nacional. Porém, para a esquerda de então, essa internacionalização era compreendida como um gesto de redenção do imperialismo e, por isso, repulsada pelo grupo. No caminho contrário, os tropicalistas demonstravam curiosidade pelas inovações e receptividade à incorporação de diversas propostas ideológicas (como, por exemplo, as pautas musicais da Bossa Nova e o american lifestyle da Jovem Guarda), sem especificar, porém, adesão total a nenhuma.

Entretanto, vale reiterar que, mesmo com a discordância em relação à influência estrangeira na MPB, a esquerda e o tropicalismo, diante do regime militar, eram unânimes em uma pauta decisiva: a defesa da democracia. Prova disso é o fato de 
figuras centrais do movimento terem sido censuradas, presas e exiladas 5 pelo fato de inaugurarem "um tipo inédito de fazer canção no país [...]" (FAVARETTO, 1996, p. 130). ${ }^{6}$

Veloso, ao adotar uma "mensagem alternativa, passando por cima de sua demonização pela esquerda" (MONTEIRO, 2012), sentia-se aliviado. ${ }^{7}$ A não total identificação de Veloso com a esquerda nunca foi, para ele, assunto a ser evitado. Essa ala política é, inclusive, ironizada na canção "Eles", de 1968 (QR Code 1): "E pior a emenda do que o soneto/Está sempre à esquerda a porta do banheiro/E certa gente se conhece no cheiro $[\ldots] " ;$

\section{QR Code 1}

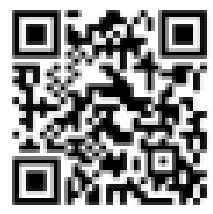

5 Sem acusação formal ou processo tramitando contra Caetano e o amigo Gilberto Gil, ambos foram submetidos à prisão domiciliar, sendo obrigados a se apresentar diariamente na Polícia Federal, sem poder trabalhar com música ou até mesmo sair de Salvador. A situação foi reconhecida como estranha inclusive pelo coronel Luis Artur, chefe da Polícia Federal soteropolitana. Por conselho de militares do Rio de Janeiro, Veloso e Gil deixaram o país e se exilaram em Londres entre 1969 e 1972. Em 1971, Caetano visitou brevemente o Brasil apenas para participar da cerimônia de 40 anos de casamento dos seus pais - essa vinda só foi possível porque Maria Bethânia, irmã do músico, conseguiu autorização dos militares. Ainda assim, ao sair do avião, Veloso foi colocado dentro de um carro por militares à paisana e levado para um interrogatório que durou seis horas. Os militares o intimaram a compor uma música sobre a Transamazônica. Para convencê-lo, citaram artistas que colaboravam com o regime. Além disso, foi proibido de cortar o cabelo ou a barba (para não levantar suspeitas de que pudesse haver algo de errado com ele) e obrigado a participar de duas apresentações em programas da TV Globo (FAVERO, 2013).

6 As canções tropicalistas, dado o caráter revolucionário, abriram espaço para a criação de outros tipos de canções. Na mesma época, começaram a ser produzidas as canções-protesto, faixas que explicitamente se manifestavam contra a ditadura que se instaurou no Brasil. Alguns exemplos: Vai (Menina, amanhã de manhã) (Tom Zé, 1972), Apesar de você (Chico Buarque, 1970), Caminhando/Pra não dizer que não falei das flores (Geraldo Vandré, 1968), Mosca na sopa (Raul Seixas, 1973) etc. Entretanto, não se pode confundir as canções tropicalistas com as de protesto, equívoco muito comum quando se fala da música brasileira durante o período ditatorial.

7 'Quando o poeta de Terra em transe decretou a falência da crença nas energias libertadoras do 'povo', eu, na plateia, vi não o fim das possibilidades, mas o anúncio de novas tarefas para mim [...]” (VELOSO, 1997, p. 116). Caetano se refere, nesse trecho, a uma cena em que um intelectual aliado do Partido Comunista tapa com a mão a boca de um líder sindical ao mesmo tempo que se dirige ao público afirmando que o povo é um analfabeto, um imbecil e um despolitizado. Segundo Schwarz (2012, p. 77), "do ponto de vista da esquerda, a cena - uma invenção artística de primeira força - era um compêndio de sacrilégios, fazendo uma espécie de chacota dolorosa das certezas ideológicas do período. Os trabalhadores estavam longe de ser revolucionários, a sua relação com os dirigentes pautava-se pelo paternalismo, os políticos populistas se acertavam com o campo adversário, a distância entre as teses marxistas e a realidade social era desanimadora, e os intelectuais confundiam as razões da revolução política e as urgências da realização pessoal [...]". 
Como símbolo mais forte (e irado) dessa relação com a esquerda, há o discurso proferido no Festival Internacional da Canção (FIC), em 1968 no teatro TUCA em SP. Recebendo vaias de uma plateia de estudantes esquerdistas após a execução de "É proibido proibir", improvisou uma fala que tinha como síntese a ideia de que aquele posicionamento político era atrasado:

Mas é isso que é a juventude que diz que quer tomar o poder? Vocês têm coragem de aplaudir, neste ano, uma música, um tipo de música que vocês não teriam coragem de aplaudir no ano passado! São a mesma juventude que vão sempre, sempre, matar amanhã o velhote inimigo que morreu ontem. Vocês não estão entendendo nada, nada, nada, absolutamente nada. '[...] O problema é o seguinte: estão querendo policiar a música brasileira. [...] Eu vim aqui para acabar com isso! Gilberto Gil está aqui comigo, para nós acabarmos com o festival e com toda a imbecilidade que reina no Brasil. [...] Se vocês, em política, forem como são em estética, estamos feitos! (transcrição nossa).

Enquanto a esquerda nacionalista posicionava-se contra as inovações culturais sugeridas pelo movimento, Caetano objetivava, por meio do movimento, romper $^{8}$ com essa resistência.

Ainda como prova dessa tensão, como algo durável ao longo dos anos, em entrevista concedida à Folha de S. Paulo em 2012, Caetano aponta um possível silenciamento de intelectuais de esquerda, como Roberto Schwarz e também Marilena Chaui, a respeito do totalitarismo em regimes comunistas (cita China e Coreia do Norte): "Sempre me pergunto por que Roberto Schwarz ou Marilena Chaui nunca têm nada a dizer sobre o que se passa na Coreia do Norte [...]" (VELOSO, 2012). Além disso, já questionou a negação, por parte do ex-presidente Lula, de

8 Ou, ao menos, impedir a consolidação dessa resistência na Música Popular Brasileira. 
asilo político para atletas cubanos (VELOSO, 2012) e também a criação de campos de recuperação para homossexuais em Cuba (VELOSO, 2017).

Vale destacar, porém, que essa relação de Caetano Veloso com a esquerda ganhou novas definições em setembro de 2020. Em entrevista ao Programa do Bial (VELOSO, 2020a), na TV Globo, o músico afirmou que agora tende a ter mais respeito pelo socialismo, uma vez que enfraqueceu parte de seus posicionamentos liberais após ter contato, por recomendação do historiador pernambucano Jones Manoel, com a obra do italiano Domenico Losurdo. A influência causada pela leitura desse autor fez com que Veloso passasse a interpretar como equivocada a equalização das experiências socialistas com o nazismo, não mais aprovando, portanto, afirmações como "a extrema esquerda é igual à extrema direita [...]" (VELOSO, 2020a). Essa "revisão política" repercutiu nas redes sociais e no debate intelectual. Pablo Ortellado, professor da USP, num artigo denominado Stálin em Ipanema, escreveu que o tropicalista "traiu a biografia ao flertar com o neostalinismo [...]" (ORTELLADO, 2020). Em resposta a essa declaração, Veloso, além de considerar a polêmica "maluca", pontuou:

Não vejo nenhum neostalinismo em curso. [...] Jones Manoel nunca se disse stalinista. [...] Não diria que ele [Domenico Losurdo] seja stalinista. [...] A leitura do tropicalismo que sempre amei foi a de Augusto de Campos. Feita no calor da hora e sem nada dessa conversa de "arcaico + moderno" etc. A do marxista ocidental Roberto Schwarz, que ecoa na do liberal Ortellado, eu não sei se entendo bem. Devo reconhecer que o uso do esquema feito por Ortellado foi, a princípio, mais generoso do que o de Roberto. Resultou, porém, muito menos educado e imitou expressões como "esquerda caviar" e "radical chic" (de que eu já 
desdenhava em "Verdade Tropical"). Augusto escrevia como criador, como quem está com a mão na massa. Esses uspianos estão sempre mil furos abaixo dos concretos. (VELOSO, 2020b).

Vale observar, porém, que, com essa declaração, Caetano volta novamente a criticar o intelectualismo de esquerda ("Esses uspianos estão sempre mil furos abaixo dos concretos [...]").

\section{A prisão de Caetano}

O tropicalista, durante a efervescência do movimento, foi repentinamente preso, sem justificativas, e, mesmo no cárcere, ainda vivenciaria significativos acontecimentos individuais. Nesse sentido, o documentário Narciso em férias (TERRA; CALIL, 2020), ${ }^{9}$ estreado no Festival Internacional de Cinema de Veneza, explicita justamente a singularidade da experiência de Caetano na prisão. O artista, sozinho, sentado diante de uma parede de concreto, conta as lembranças desse episódio que vivenciou aos 26 anos.

No referido documentário, Veloso descreve a noite anterior à prisão: ele recebeu Gilberto Gil como visitante no apartamento em São Paulo e tocou no violão algumas músicas, dentre as quais estavam "Súplica” (Orlando Silva), "Assum preto" (Luiz Gonzaga), "Fracasso" (Francisco Alves) e "Onde o céu azul é mais azul" (Lula Barbosa). Com as batidas da polícia à porta logo no início da manhã, foi acordado e levado, juntamente a Gil, sem explicações, para o camburão da polícia. Quando a viatura

\footnotetext{
$9 \quad$ Antes de se tornar documentário, Narciso em férias já era um capítulo de Verdade Tropical (VELOSO, 1997). Em 2020, foi lançado como um livro à parte (VELOSO, 2020c). Em entrevista dada a Pedro Bial em 2020, o músico explicou esse título: "Em parte porque de fato, na cadeia não existia espelho nenhum. Foram quase dois meses sem espelho. Eu voltei a ver um espelho quando saí, quando cheguei em minha casa, na casa de minha família em Salvador [...]". Cita ainda que conheceu esse título no livro Este Lado do Paraiso, de Francis Scott Key Fitzgerald, o qual usava "Narciso em férias" em um de seus capítulos.
} 
pegou a estrada rumo ao Rio de Janeiro, surpreendeu-se, pois havia pensado que seria direcionado a uma delegacia próxima a sua residência. Dedé, esposa de Caetano à época, dirigindo o próprio carro, seguia o camburão a fim de acompanhar o marido para onde quer que ele fosse conduzido.

Foi jogado em uma solitária separada de seu amigo Gilberto Gil. Entre o espaço que os desunia fisicamente, cumpria pena um velho nordestino comunista que, por saber que eram músicos, pediu a Caetano que cantasse, coincidentemente, Súplica, a mesma canção que havia tocado no violão na noite anterior no apartamento em São Paulo. Essa concomitância fez com que o lado supersticioso de Veloso aflorasse: quando tocavam no radinho a pilha dos guardas as canções que participaram da noite pré-prisão (como Et maintenant, de Gilbert Bécaud), isso representaria, para ele, mais alguns dias no cárcere. Entretanto, algumas outras faixas simbolizariam a chegada de boas notícias, como era o caso de Hey Jude, dos Beatles, regravada por Caetano Veloso em 2020.

O impacto emocional fora tamanho que, conforme relata no documentário, durante esse período não conseguiu chorar, tampouco ejacular. Mostra sua face de poeta do cancioneiro brasileiro quando explica que, na tristeza, o sentimento escorre pelos olhos, transbordando o que a alma amarga, e, na alegria sexual, a alma, expelindo felicidade, se converte em esperma. $\mathrm{Na}$ prisão, por mais que tentasse se masturbar, sentia-se "deserotizado", conforme palavra que ele próprio emprega em seu relato. Atribui a impossibilidade de gozar ou chorar à alma ressequida. Conta também que sentia muito sono quando preso, o que lhe causou estranheza pois habitualmente tinha dificuldades para dormir.

$\mathrm{O}$ fato de ser transferido de quartel várias vezes fez com que sua esposa não mais soubesse onde ele estava. Seus pais 
tampouco sabiam se o filho ainda estava vivo - vale lembrar que a ditadura militar no Brasil matou inúmeras pessoas. Durante a noite, Caetano ouvia gritos de pessoas sendo torturadas. O horror e a frieza dos militares, bem como os momentos de terror psicológico, são descritos em diversas situações que o músico vivenciou na prisão. Uma das cenas mais fortes relatadas em Narciso em férias é a de quando, após um guarda parar em frente à porta da sua cela e ficar com os olhos lacrimejados, alguns militares retiraram Caetano da cela e pediram para que ele seguisse em frente, sem olhar para trás. Com as armas apontadas para ele, que andava em direção a um lugar ermo, teve convicção de que seria assassinado a tiros. O silêncio foi interrompido e trouxe alívio ao tropicalista: ele deveria subir as escadas para cortar o cabelo.

\section{Imagem 2 - À esquerda, Caetano em sua chegada à prisão, em 1968; à direita, Caetano após ter seus cabelos cortados pelos militares. ${ }^{10}$}
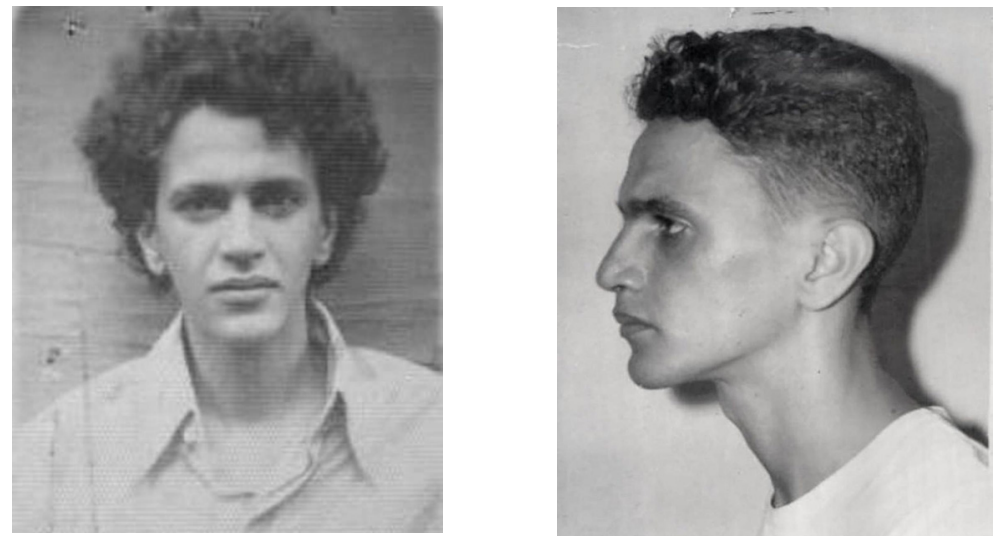

Fonte: ARQUIVO NACIONAL, FUNDO. Conselho de Segurança Nacional, notação br_dfanbsb_n8_0_pro_css_0313_d0001de0001. 1968.

10 Vale apontar que as fotos anteriores foram recoloridas por Luis Capellão em 2020. Essas versões estão disponíveis no Anexo I deste trabalho. 
Após o referido episódio, alguns colegas de prisão, quando saiam para receber visitas, contavam a Caetano que lá fora estava sua esposa à época, Dedé, gritando, na tentativa de vê-lo: os militares, entretanto, mentiam, dizendo que ele não estava ali. Dias depois, um sargento, comovido com a situação e com a insistência da esposa, às escondidas passou a permitir a entrada dela enquanto vigiava o corredor para que ninguém a visse.

Em uma dessas visitas, Dedé levou ao marido uma revista com a primeira foto do planeta terra visto do espaço. Isso resultaria, dez anos depois, na canção Terra (1978 - QR Code 2), na qual se lê: "Quando eu me encontrava preso, na cela de uma cadeia/Foi que eu vi pela primeira vez, as tais fotografias/Em que apareces inteira, porém lá não estava nua/E sim coberta de nuvens/Terra, terra,/Por mais distante o errante navegante/Quem jamais te esqueceria $[\ldots]$ "...

\section{QR Code 2}

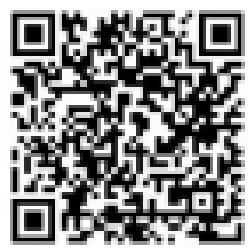

No documentário, ao reencontrar essa revista, com um dos diretores entregando-a em mãos, se emociona, chora e pede para parar de falar por um momento.

Ainda sem saber o motivo pelo qual fora preso, ansiava pelo momento em que teria explicações e também pelo momento em que seria ouvido. Ao longo de todo o Narciso em férias, é reiterada por diversas vezes a demora da chegada do interrogatório. 
Quando finalmente é convocado para depor, descobre o motivo da prisão: o jornalista Randal Juliano lera, em um programa de televisão, uma nota de jornal que acusava Caetano e Gil de cantarem, em um show na boate Sucata, no Rio de Janeiro, o hino nacional brasileiro em forma de paródia. A falsa notícia foi desmentida pelo tropicalista e por uma testemunha apontada por ele: Ricardo Amaral, proprietário da mesma boate (VELOSO, 2020).

Diante do nervosismo pelo fato de ser interrogado pelos militares e também pelos rumos que aquela situação poderia dar ao seu futuro, Caetano relata, em Terra e Calil (2020), que durante o depoimento não mentiu, porém procurou dar respostas que não o penalizassem com o aumento do seu tempo de prisão. A única canção composta nesse período (Irene, de 1969 - QR Code 3) explicita a ânsia pela liberdade: "Eu quero ir, minha gente, eu não sou daqui/Eu não tenho nada, quero ver Irene rir/ Quero ver Irene dar sua risada (2x)/Irene ri, Irene ri, Irene [...]”.

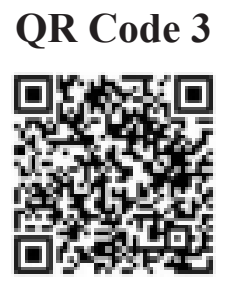

Além disso, a composição é aparentemente motivada pelas saudades de sua irmã, Irene Velloso. Por pertencer a uma família extremamente unida, a ausência de seus pais e irmãos foi muito sentida por ele nesse período. Inclusive, durante o interrogatório, os militares pediram informações muito específicas sobre seus familiares, como, por exemplo, endereço e local de trabalho. "Eu 
percebia que era uma coisa, por um lado, hiperburocrática, mas também tinha um toque de ameaça. Em qualquer situação, eles tinham coberto toda minha parentela [...]" (VELOSO, 2020c, p. 147).

Em abril de 2018, o historiador Lucas Pedretti descobriu no Arquivo Nacional os documentos do processo aberto pela ditadura militar contra Caetano Veloso.

\section{Imagem 3 - Trecho do registro do interrogatório de Caetano, realizado em 1969}

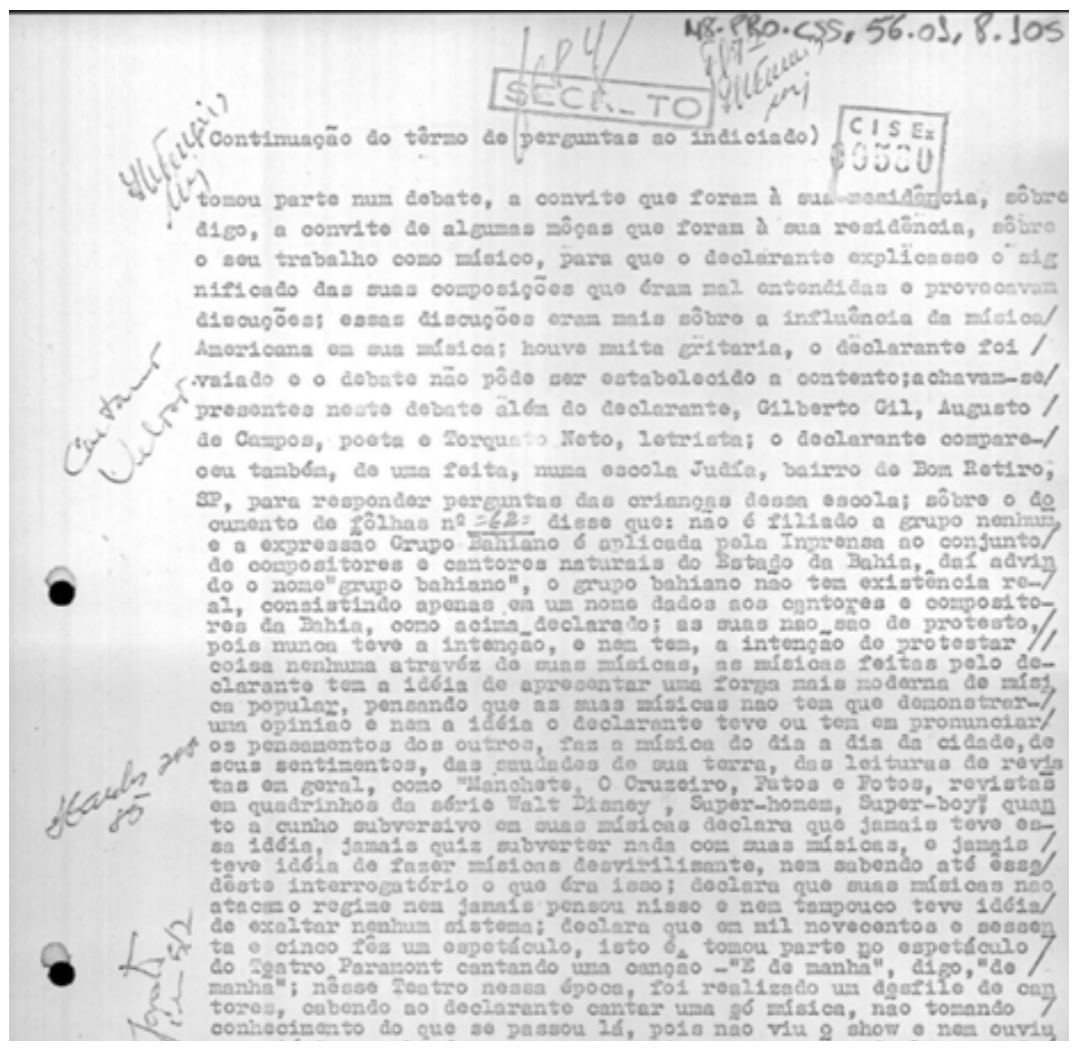

Fonte: ARQUIVO NACIONAL, FUNDO. Conselho de Segurança Nacional, notação br_dfanbsb_n8_0_pro_css_0313_d0001de0001. 1968. 
Em um fragmento desse documento, lê-se: “[...] quanto a cunho subversivo em suas mísicas [sic] declara que jamais teve essa idéia, jamais quiz [sic] subverter nada com suas músicas, e jamais teve idéias de fazer mísicas [sic] desvirilisante [sic], nem sabendo até êsse dêste $[s i c]$ interrogatório o que éra isso [...]".

Em outra página, constata-se que um motivo secundário para a prisão do tropicalista teria sido o lançamento de um disco chamado Che, o qual nunca existiu. Vê-se aqui outra inverdade que ocasionou a prisão. O principal motivo, porém, como mencionado, fora a acusação de ter cantado o hino brasileiro, segundo os documentos oficiais, em "ritmo de Tropicália" expressão que por si só denuncia imprecisão ou desconhecimento por parte dos acusadores, dado que a Tropicália nunca foi um ritmo musical, mas, sim, um movimento artístico, ou seja, não se reduz a uma espécie de manifestação, pois o tropicalismo reverberou também, por exemplo, no cinema, no teatro e nas artes plásticas. Vale ainda ressaltar os inúmeros desvios à norma padrão e erros de digitação ao longo de todo o documento. Nos arquivos descobertos por Pedretti, encontra-se também um compilado de canções da autoria de Caetano, as quais formam uma espécie de dossiê (Anexos II e III).

Os relatos da prisão de Caetano evidenciam a singularidade dessa experiência: as desesperadas e raras visitas de sua então esposa Dedé; a criação de um místico sistema de sinais (que em tese diriam sobre o tempo de permanência que ainda the restaria na cela); a descrita impossibilidade de durante a prisão chegar aos "líquidos da alma" (choro e ejaculação); a ausência dos familiares; as situações de terror psicológico, e a descoberta em uma revista de uma (à época inédita) fotografia do globo terrestre, experiência retratada na canção Terra (1978). Nesse 
sentido, o documentário Narciso em férias (TERRA; CALIL, 2020) tem emocionado diversas pessoas, as quais fazem questão de registrar suas impressões sobre o filme nas mais diversas redes sociais.

\section{0 aspecto cancional}

A não consideração do aspecto musical para analisar um movimento que foi majoritariamente musical mostra-se desproveitoso, ${ }^{11}$ como acontece em Schwarz (2005; 2021). $\mathrm{O}$ gênero discursivo ${ }^{12}$ canção como um recurso para registro de ideais sempre foi defendido pelo tropicalismo, motivando inclusive anos depois o seguinte verso em Língua (1984-QR Code 4), do próprio Caetano: "Se você tem uma ideia incrível/É melhor fazer uma canção,/Está provado que só é possível/ Filosofar em alemão [...]".

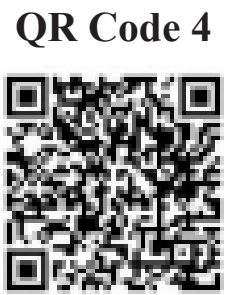

11 Pode-se, inclusive, atribuir a recorrente desimportância que o gênero canção enfrenta academicamente ao recorrente negligenciamento que os gêneros orais sofrem sobretudo nas escolas, mas também nas universidades brasileiras, que privilegiam o trabalho com textos escritos (MARCUSCHI, 1997; BENTES, 2010; ROJO, 2012; SIMÕES; NEVES, 2017). Vale ainda defender que analisar canções não é somente se restringir à letra, visto que o gênero em análise é um conjugado entre o âmbito escrito (letra) e o oral (música, prosódia), tendo um caráter híbrido e intersemiótico (TATIT, 1996; COSTA, 2005; ROJO, 2012).

12 Segundo Bakhtin (2003, p. 261), "o emprego da língua efetua-se em forma de enunciados (orais e escritos) concretos e únicos, proferidos pelos integrantes desse ou daquele campo da atividade humana. [...] Cada enunciado particular é individual, mas cada campo de utilização da língua elabora seus tipos relativamente estáveis de enunciados, os quais denominamos gênero do discurso [...]" (grifo do texto original). Pelo gênero canção apresentar temática, estilo e estrutura composicional estáveis, Piedade (2003) o relaciona com o conceito bakhtiniano. 
Nesse trecho, portanto, além da explanação a respeito do predomínio de pensadores alemães no estudo de filosofia, defende-se a música como um mecanismo de expressão de convicções. Tal característica é coerente com a obra de seu autor, pois, se pensarmos no Tropicalismo, Alegria, alegria (1968-QR Code 5), como já dito anteriormente, é uma canção que resume com objetividade e precisão a essência do movimento. Abaixo há a letra na íntegra, seguida de uma análise que elaborei: ${ }^{13}$ Podese encontrar o link para a audição desta faixa no Youtube, em sua gravação original, ao final deste trabalho, na seção "Canções citadas ao longo deste trabalho".

\section{QR Code 5}

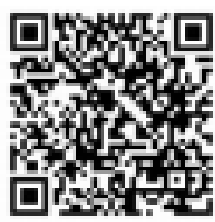

Caminhando contra o vento

Sem lenço e sem documento

No Sol de quase dezembro

Eu vou

O Sol se reparte em crimes

Espaçonaves, guerrilhas

Em Cardinales bonitas

Eu vou

Em caras de presidentes

Em grandes beijos de amor

Em dentes, pernas, bandeiras

Bomba e Brigitte Bardot

O Sol nas bancas de revista

Me enche de alegria e preguiça

Quem lê tanta notícia?

13 Pode-se encontrar o link para a audição dessa faixa no YouTube, em sua gravação original, na lista de referências ao final deste trabalho. 
Eu vou

Por entre fotos e nomes

Os olhos cheios de cores

O peito cheio de amores vãos

Eu vou

Por que não? Por que não?

[...]

Eu tomo uma Coca-Cola

Ela pensa em casamento

E uma canção me consola

Eu vou

Por entre fotos e nomes

Sem livros e sem fuzil

Sem fome, sem telefone

No coração do Brasil

Ela nem sabe, até pensei

Em cantar na televisão

O Sol é tão bonito

Eu vou

Sem lenço, sem documento

Nada no bolso ou nas mãos

Eu quero seguir vivendo, amor

Eu vou

Por que não? Por que não?

(3x)

O eu-lírico da canção, diante de uma banca de revistas, observa nas manchetes, de modo dinâmico, cinematográfico e cubista, os principais acontecimentos ao redor do mundo (espaçonaves, guerrilhas, caras de presidentes, beijos de amor etc. - possivelmente os trechos que mais evidenciam isso são os que citam as atrizes Brigitte Bardot e Claudia Cardinale) e 
se interessa por todos esses feitos, ${ }^{14}$ pelo aspecto globalizado da informação, pelas inovações. O sujeito vê os acontecimentos com alegria (nesse sentido, "os olhos cheios de cores" representam o deslumbramento do eu-lírico com a diversidade típica das manchetes justapostas em bancas de jornais), ao mesmo tempo que é tomado pela preguiça: "sem lenço, sem documento" simboliza o descompromisso com a adesão total a algum desses acontecimentos ou pautas. Ainda que ele beba uma Coca-Cola (uma metáfora para a adesão à influência estrangeira), prefere estar "sem livros" (o que pode representar o intelectualismo da esquerda) e também "sem fuzil" (uma referência ao aspecto militar e ditatorial do fim da década de 60 , ou quem sabe até às guerrilhas armadas).

O fato de o gênero canção reunir dois tipos de linguagens, a verbal e a musical, caracteriza-o como híbrido e intersemiótico (TATIT, 1996; COSTA, 2005): ou seja, as análises de canção devem procurar contemplar também o aspecto sonoro, não só o escrito (MARTINS et al., 2009), recorrendo a uma perspectiva multimodal (ROJO, 2012). No caso de Alegria, alegria, além da presença de guitarras elétricas, instrumento que praticamente foi uma das bandeiras tropicalistas, o âmbito musical reforça a mensagem transmitida pela letra. Por exemplo, somente os trechos "Em caras de presidentes/ Em grandes beijos de amor/ Em dentes, pernas, bandeiras/ Bomba e Brigitte Bardot" e "Por entre fotos e nomes/ Sem livros e sem fuzil/ Sem fome, sem telefone/ No coração do Brasil", justamente os que elencam os elementos diversos que o eu-lírico observa na banca de revista,

\footnotetext{
14 Nesse ponto, vê-se novamente a influência do modernismo brasileiro sobre a proposta tropicalista, uma vez que há completa similaridade com o conceito de antropofagia desenvolvido por Oswald de Andrade. A proposta do poeta modernista era reunir à cultura local influências relevantes do estrangeiro. Para isso, seria necessário, portanto, absorver criticamente o que outras fontes culturais teriam para oferecer (ou seja, abrir-se e não se fechar, devorando novas ideias - daí o nome que se relaciona a canibalismo). Coca-Cola, Claudia Cardinale e Brigitte Bardot são referências à cultura do exterior.
} 
apresentam mais de um acorde por palavra, o que reforça o caráter fragmentário e cubista do trecho - é como se as palavras, nesses trechos, se "picotassem" entre variadas notas. A cifra presente no songbook Caetano Veloso evidencia esse acontecimento:

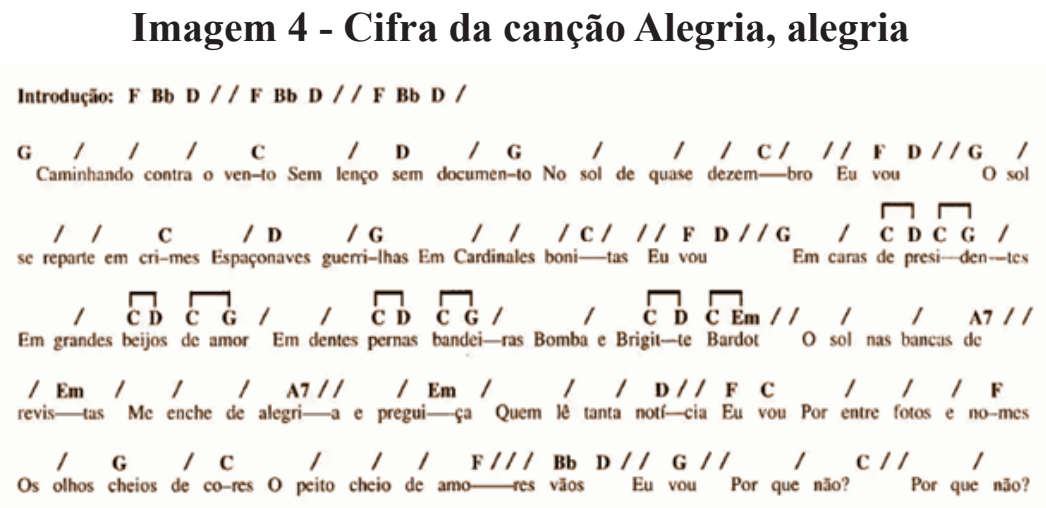

Fonte: Chediak (1997, p. 37)

No songbook, um sinal gráfico semelhante a um colchete horizontal reitera que dois acordes se dividem entre a mesma palavra, como é o caso de "pernas", "bandeiras", "Bardot”. Ou seja, o aspecto cubista não pode ser encontrado apenas na letra da canção, mas também em sua sonoridade.

Além disso, o trecho "O Sol nas bancas de revista/ Me enche de alegria e preguiça" é cantado por Caetano em ritmo mais lento, destoando da "levada" anterior da faixa, sendo inclusive acompanhado por uma condução também mais vagarosa dos instrumentos musicais: tal recurso reforça a ideia de preguiça expressa na letra. Como mencionado, no contexto tropicalista, esse descompromisso simboliza a recusa à militância por uma das pautas elencadas. Por fim, vale mencionar que o título da canção é uma referência ao bordão de Chacrinha (Alegria, 
alegria!), apresentador de TV, cujo programa tinha um caráter "anárquico" (VELOSO, 1997, p. 166), classificado por Caetano como "dono de uma liberdade cênica" (VELOSO, 1997), pois interrompia os participantes com uma buzina e atirava bacalhau na plateia - somando essa referência ao verso retirado da última página de As palavras, de Sartre ("nada no bolso ou nas mãos"), a canção também reforça a "geleia geral" tropicalista ao combinar um apresentador de programa popular com um filósofo francês considerado como um dos mais complexos.

Outra canção que sintetiza com clareza as ideias do movimento é Baby, de 1968 ( $Q R$ Code 6), a qual também constava no dossiê de Caetano elaborado pela ditadura militar (Anexo III):

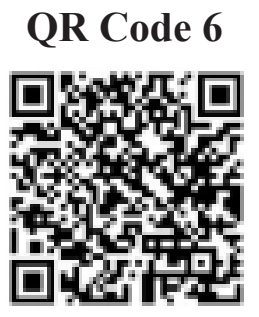

Você precisa

Saber da piscina

Da margarina

Da Carolina

Da gasolina

Você precisa

Saber de mim

Baby, baby

Eu sei

Que é assim

Baby, baby

Eu sei

Que é assim 


\section{"Alegria, alegria" e "Baby": as canções síntese do movimento tropicalista}

Você precisa

Tomar um sorvete

$\mathrm{Na}$ lanchonete

Andar com gente

Me ver de perto

Ouvir aquela canção

Do Roberto

Baby, baby

Há quanto tempo

Baby, baby

Há quanto tempo

Você precisa

Aprender inglês

Precisa aprender

$O$ que eu sei

E o que eu

Não sei mais

E o que eu

Não sei mais

Não sei

Comigo

Vai tudo azul

Contigo

Vai tudo em paz

Vivemos

Na melhor cidade

Da América do Sul

Da América do Sul

Você precisa

Você precisa...

Não sei

Leia

Na minha camisa

Baby, baby

I love you

Baby, baby

I love you... 
A canção se inicia com sons de guitarra e violinos, incrementados pouco depois por uma marcação percussiva. As referências à faixa Carolina, cantada por Chico Buarque e lançada também em 1968, e àquela "canção do Roberto", metonímias para a MPB e a Jovem Guarda, respectivamente, fazem de Baby, em que o pano de fundo é justamente a nova sonoridade proposta pelo movimento, o epítome do ideário tropicalista. $\mathrm{O}$ arranjo de Rogério Duprat, com ritmo descontraído, dá a essa canção uma atmosfera sonhadora, a qual pode levar o ouvinte a um delírio (STEELY, 2013), possibilitado pela sonoridade psicodélica dessa versão original. Para além da interação com o ouvinte, é proposto um convite de adesão à proposta tropicalista por meio da palavra "você", no verso "você precisa [...] andar com a gente", seguido de referências as quais o interlocutor precisa conhecer.

É notória também a recorrência da cultura estrangeira na letra dessa canção. Tanto o conselho de aprender inglês, quanto a presença da lanchonete (do inglês luncheonette), que precisa ser visitada para tomar um sorvete, desaguam sempre na melodiosa repetição do termo baby. Possivelmente, classificar São Paulo como a "melhor cidade da América do Sul", seguido pela repetição de "América do Sul", é uma forma de nos lembrar que, de um modo ou de outro, em linhas gerais, também somos americanos.

No final, ainda, quando Gal termina a repetição ${ }^{15}$ do verso “Baby, I love you”, Veloso no contracanto completa: "oh, please, stay by me Diana" citando Diana, grande sucesso do final dos anos 1950 do norte-americano Paul Anka. Mais interessante ainda é que, em clipe lançado em 2019 (QR Code 7), ao cantar Baby ao lado dos filhos, no fim da canção Caetano brinca com a

15 Essa repetição, enfática, serve como afirmação da proposta tropicalista: era então preciso se abrir às inovações do mundo moderno. 
semelhança fonética da pronúncia de Diana em inglês com a de "baiana" em português, o que por si só resume com exatidão o sincretismo tropicalista.

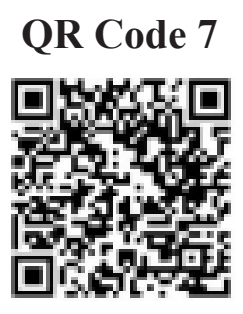

\section{Considerações finais}

Conclui-se que o tropicalismo defendia um caráter incorporador, agregando os contrastes existentes no país como sendo naturalmente partes da própria cultura nacional, somandoos também às inovações do mundo pop, engrossando desse modo a "geleia geral". O movimento enxergava justamente na diversidade cultural a beleza do território. Interpreta-se a nação com um lugar a ser preenchido com a globalização - o contrário simbolizaria retrocesso.

Vê-se, portanto, que a Tropicália, por ser um movimento artístico, apresentou suas ideias principalmente por meio da música, mas também por meio do cinema, do teatro e das artes plásticas. Espero, aqui, ter mostrado como as canções analisadas expressam com precisão os ideais propostos pelo movimento e reiterado a importância de se levar em conta a sonoridade nas análises de canções.

Por fim, vale registrar que Caetano, mesmo atualmente, aos 79 anos de idade, mostra-se um incansável tropicalista: tem participado e liderado organizações em defesa da democracia 
e do meio ambiente, como o 342 Artes e o 342 Amazônia. No âmbito musical, demonstra ainda um interesse pela inovação, explorando, em sua nova turnê junto a Ivan Sacerdote temporariamente adiada devido à pandemia de Covid-19 -, a relação entre voz e clarinete, combinação que anteriormente fora negligenciada na história da Música Popular Brasileira. A esquerda, porém, demonstra dificuldades de organização e articulação para poder enfrentar concretamente o difícil, obscuro e retrocessivo momento pelo qual passa o Brasil.

\section{Referências}

ALEGRIA, Alegria (Remastered 2006). Intérprete: Caetano Veloso. In: CAETANO Veloso. Compositor e letrista: Caetano Veloso. [S. l.]: Universal Music Ltda., 1967. Disponível em: https://www.youtube.com/watch?v=he_ghOAXbSM. Acesso em: 21 dez. 2021.

ARQUIVO NACIONAL, FUNDO. Conselho de Segurança Nacional, notação br_dfanbsb_n8_0_pro_css_0313 d0001de0001. 1968.

BABY. Intérprete: Gal Costa e Caetano Veloso. [S. l.]: Claudinei Sampaio, 4 jul. 2013. 1 vídeo (3 min. 27 seg.) Publicado por Claudinei Sampaio. Disponível em: https://www.youtube.com/ watch?v=1XSQwHJLT48. Acesso em: 21 dez. 2021.

BAKHTIN, M. Gêneros do Discurso. In: BAKHTIN, Mikhail. Estética da criação verbal. Tradução de Marina Appenzellerl. São Paulo: Martins Fontes, 2003, p. 261-306.

BENTES, A. C. Linguagem oral no espaço escolar: rediscutindo o lugar das práticas e dos gêneros orais na escola. In: RANGEL, E. G.; ROJO, R. Língua Portuguesa. Coleção Explorando o Ensino. Brasília - MEC, vol. 19, p. 129-154, 2010. 
BORGES, A. C. Cantar é mais do que lembrar: memórias e autoconstrução intelectual de Caetano Veloso em Verdade Tropical. 2019. Dissertação (Mestrado em História, Política e Bens Culturais) - Fundação Getúlio Vargas, Rio de Janeiro, 2019. Disponível em: https://bibliotecadigital.fgv.br/dspace/bitstream/ handle/10438/28088/disserta\%c3\%a7\%c3\%a3o_carol_borges. pdf?sequence=1\&isAllowed=y. Acesso em: 21 dez. 2021 .

CAETANO Veloso e os Mutantes É Proibido Proibir (discurso legendado). [S. l.]: Júlio Geo, 4 jul. 2014. 1 vídeo (10 seg.). Publicado por Júlio Geo. Disponível em: https://www.youtube. com/watch?v=4xEz2uva_ZE. Acesso em: $21 \mathrm{dez} .2021$.

CAETANO Veloso - Língua. Intérprete: Caetano Veloso. [S. l.]: Universal Music Ltda., 2012. 1 vídeo (3 min. 35 seg.). Publicado por: Caetano Veloso. Disponível em: https://www.youtube.com/ watch?v=tX7cqBreLUY. Acesso em: 21 dez. 2021.

CAETANO Veloso, Moreno Veloso, Zeca Veloso e Tom Veloso - Baby. [S. l.]: Equipe Spray Filmes, 12 jul. 2019. 1 vídeo (4 min. 44 seg.). Publicado por Caetano Veloso. Disponível em: https://www.youtube.com/watch?v=KMTA5vxsssg. Acesso em: 21 dez. 2021.

CALIL, R.; TERRA, R. Uma noite em 67. Rio de Janeiro: VideoFilmes, Record Entretenimento, 2010. Disponível em: https://www.youtube.com/watch?v=MLdptXDGwmg. Acesso em 13 abr. 2020.

CHEDIAK, A. Songbook - Caetano Veloso - v. 1. RJ: Lumiar, 1997.

COSTA, N. B. DA. As letras e a letra: o gênero canção na mídia literária. In: DIONISIO, A. P.; MACHADO, A. R.; BEZERRA, M. A. (org.). Gêneros textuais e ensino. 4. ed. Rio de Janeiro: Lucerna, 2005.

DUARTE, P. A alegoria tropicalista do absurdo. Viso: Cadernos de estética aplicada, v. XII, n. 23, jul.-dez. 2018. Disponível em: 
http://revistaviso.com.br/pdf/Viso_23_PedroDuarte.pdf. Acesso em 13 jun. 2019.

FAVARETTO, C. Tropicália: Alegoria, Alegria. 2. ed. Prefácio de Luiz Tatit. São Paulo: Ateliê Editorial, 1996.

FAVERO, D. Presos há 45 anos, Gil e Caetano foram vítimas do AI-5 e tiveram que se exilar. Política Terra, 23 dez. 2013. Disponível em: https://www.terra.com.br/noticias/brasil/ politica/presos-ha-45-anos-gil-e-caetano-foram-vitimas-do-ai5-e-tiveram-que-se-exilar,9b62d3a863c03410 VgnVCM200000 99cceb0aRCRD.html. Acesso em 29 out. 2020.

GARSON, M. Jovem Guarda versus MPB:A construção midiática da guerra. Revista Famecos, Porto Alegre, v. 25, n. 3, p. 1-21, set.-dez. 2018. Disponível em: https://revistaseletronicas.pucrs. br/ojs/index.php/revistafamecos/article/view/29728/17225. Acesso em 31 jul. 2020.

GUIA interativo sobre os festivais de MPB. GZH, 20002015. Disponível em: http://www.clicrbs.com.br/sites/swf/zhfestivais-mpb/record-67.html. Acesso em 05 jun. 2020.

IRENE (Remastered 2006). Intérprete: Caetano Veloso. In: CAETANO Veloso. Compositor e letrista: Caetano Veloso. [ $S$. l.]: Universal Music Ltda., 1969. Disponível em: https://www. youtube.com/watch? $\mathrm{v}=\mathrm{INA} 4 \mathrm{Tc} 0 \mathrm{qV} \mathrm{VE}$. Acesso em: $21 \mathrm{dez}$. 2021.

JULIÃO, R. B. Infinitivamente pessoal: a verdade tropical de Caetano Veloso. 2016. Tese (Doutorado em Letras) Universidade Federal do Rio de Janeiro, Rio de Janeiro, 2016. Disponível em: http://www.posvernaculas.letras.ufrj.br/images/ Posvernaculas/4-doutorado/teses/2016/19-JuliaoRB.pdf. Acesso em: 28 abr. 2020.

MARCUSCHI, L. A. Concepção de língua falada nos manuais de português de $1^{\circ}$ e $2^{\circ}$ graus: uma visão crítica. Trab. Ling. Apl., Campinas, (30):39-79, Jul/Dez. 1997. Disponível em: 
https://www.ufjf.br/projetodeoralidade/files/2018/06/LDConcep\%c3\%a 7\%c3\%a3o-de-Lingua-Falada-nos-manuais-dePortugu\%c3\%aas-de-1-e-2-graus-uma-vis\%c3\%a3o-criticaMARCUSCHI-Luis-Antonio-1997.pdf. Acesso em 27 dez. 21.

MARTINS, NOARA BOLZAN et al. A utilização da música como prática de ensino nos livros didáticos. Vivências, v. 5, n. 8, p. 77-83, out. 2009. Disponível em: http://www2.reitoria. uri.br/ vivencias/Numero_008/artigos/artigos_vivencias_08/ Artigo_35.pdf. Acesso em: 13 jul. 2020.

MONTEIRO, P. M. O que é isso, Caetano? Revolução, culpa e desejo. Serrote, n. 12, nov. 2012. Disponível em: https:// meiramonteiro.com/o-que-e-isso-caetano-revolucao-culpa-edesejo. Acesso em: 13 nov. 2019.

NAPOLITANO, M.; VILLAÇA, M. M. Tropicalismo: As Relíquias do Brasil em Debate. Rev. bras. Hist., São Paulo, v. 18, n. 35, p. 53-75, 1998. Disponível em: http://www.scielo.br/scielo. php?script=sci_arttext\&pid=S0102-01881998000100003\&lng= en\&nrm=iso. Acesso em: 13 jun. 2019.

ORTELlADO, P. Stálin em Ipanema. Folha de S. Paulo, São Paulo, 14 set. 2020. Disponível em: https://www1.folha.uol. com.br/colunas/pablo-ortellado/2020/09/stalin-em-ipanema. shtml. Acesso em: 30 set. 2020.

PIEDADE, A. T. C. Brazilian Jazz and Friction of Musicalities. In: TAYLOR, E. Atkins (org.). Jazz Planet. Jackson: University Press of Mississippi, 2003. p. 41-58.

ROJO, R. Pedagogia dos multiletramentos. In: ROJO, Roxane; MOURA,

Eduardo. Multiletramentos na escola. Parábola Editorial: São Paulo, 2012. p. 11-31.

SANTOS, D. V. As representações de nação nas canções de Chico Buarque e Caetano Veloso: do nacional-popular à mundialização. Tese (Doutorado em Sociologia) - Universidade 
Estadual de Campinas: Campinas, 2014. Disponível em: https:// bdtd.ibict.br/vufind/Record/CAMP_8b5428509e6ce552b3914 1f674648300. Acesso em 21 out. 2019.

SCHWARZ, R. Cultura e política. São Paulo: Paz e Terra, 2005.

SCHWARZ, R. Verdade Tropical: um percurso de nosso tempo. In: SCHWARZ, R. Martinha versus Lucrécia - ensaios e entrevistas. São Paulo: Companhia das Letras, 2012.

SIMÕES, P. H. O. ; NEVES, C. A. B. Especificidade da literatura e formação do leitor: reflexões sobre o ensino-aprendizagem de língua(gens). Revista Caminhos em Linguística Aplicada, v. 17, n. 3, p. 227-243, 2017. Disponível em: http://periodicos. unitau.br/ojs-2.2/index.php/caminhoslinguistica. Acesso em: 13 ago. 2020.

STEELY, L. Analepse Tropicália: "Baby" e a Cultura do Consumidor. Hacking Portuguese, 27 mar. 2013. Disponível em: http://hackingportuguese.com/2013/03/analepse-tropicaliababy/. Acesso em 10 nov. 2020.

TATIT, L. O cancionista: composição de canções no Brasil. São Paulo: EDUSP, 1996.

TERRA, R; CALIL, R. Narciso em férias (documentário). GloboPlay: 7 set. 2020. 1h23. Disponível em: https://globoplay. globo.com/v/8836951/programa. Acesso em 27 dez. 21.

TROPICÁLIA. In: ENCICLOPÉDIA Itaú Cultural de Arte e Cultura Brasileiras. São Paulo: Itaú Cultural, 2020. Disponível em: http://enciclopedia.itaucultural.org.br/termo3741/tropicalia. Acesso em: 05 de Jun. 2020.

VELOSO, C. Caetano Veloso e os elegantes uspianos. [Entrevista cedida a] P. Werneck. Folha de S. Paulo, São Paulo, Ilustríssima, 15 abr. 2012. Disponível em: https://www1.folha.uol.com.br/ fsp/ilustrissima/37126-caetano-veloso-e-os-elegantes-uspianos. shtml. Acesso em: 09 jul. 2020.

VELOSO, C. Carmen Miranda não sabia sambar. In: VELOSO, 
C. Verdade tropical. 3. ed. São Paulo: Companhia das Letras, 2017.

VELOSO, C. (2020b) Não vejo nenhum neostalinismo em curso, e polêmica é maluca, diz Caetano [Entrevista concedida a] Marcos Augusto Gonçalves. Folha de S. Paulo, São Paulo, Ilustríssima, 24 set. 2020. Disponível em: https://www1. folha.uol.com.br/ilustrissima/2020/09/nao-vejo-nenhumneostalinismo-em-curso-e-polemica-e-maluca-diz-caetano. shtml. Acesso em 30 set. 2020.

VELOSO, C. (2020a) Programa de 04/09/2020. [Entrevista cedida a] Pedro Bial. Conversa com Bial, São Paulo: Rede Globo, 4 set. 2020. Disponível em: https://globoplay.globo. com/v/8833147/programa/?s=07s. Acesso em: 27 dez. 2021.

VELOSO, C. (2020c) Narciso em férias. São Paulo: Companhia das Letras, 2020.

VELOSO, Caetano. O mundo não é chato. São Paulo: Companhia das Letras, 2005.

VELOSO, C. Site oficial - biografia. Disponível em: http://www. caetanoveloso.com.br/biografia. Acesso em 10 mai. 20.

VELOSO, C. Verdade tropical. São Paulo: Companhia das Letras, 1997.

VELOSO, C. Verdade tropical. 3. ed. São Paulo: Companhia das Letras, 2017.

WISNIK, G. Folha explica Caetano Veloso. São Paulo: Publifolha, 2005. 
ANEXO I - Imagens de Caetano Veloso na prisão, em 1968, recoloridas por Luis Capellão em 2020

Imagem 1 - Caetano Veloso antes de ter seu cabelo cortado pelas forças de repressão

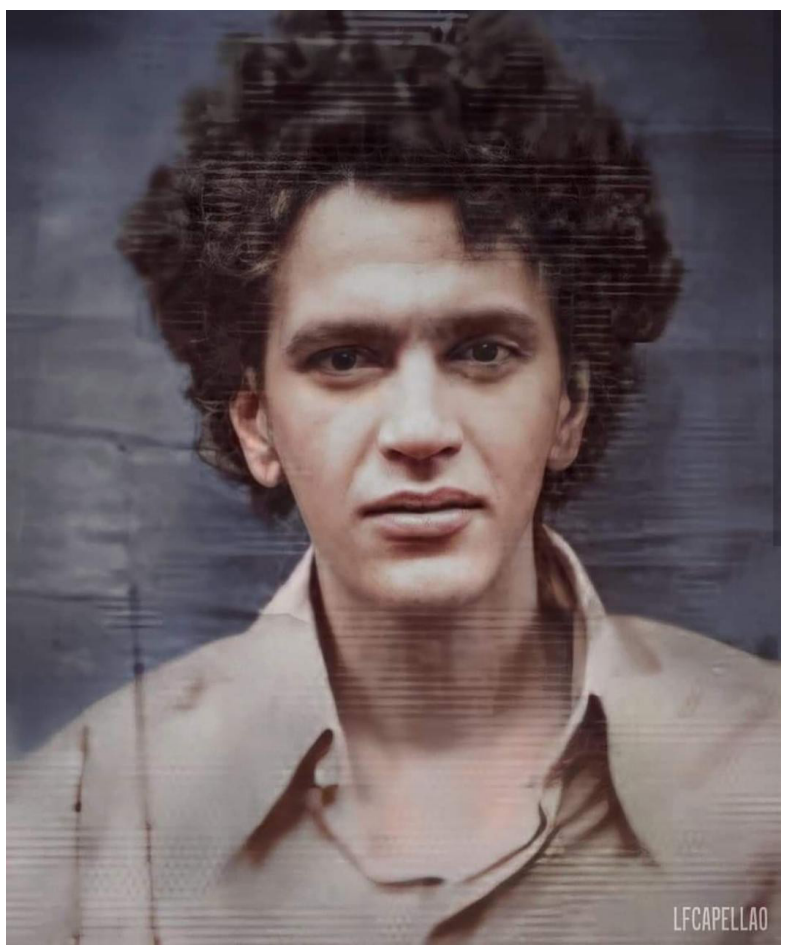

Fonte: Instagram de Luis Capellão ${ }^{16}$ 
“Alegria, alegria" e "Baby": as canções síntese do movimento tropicalista

Imagem 2 - Caetano Veloso após ter seu cabelo cortado pelas forças de repressão

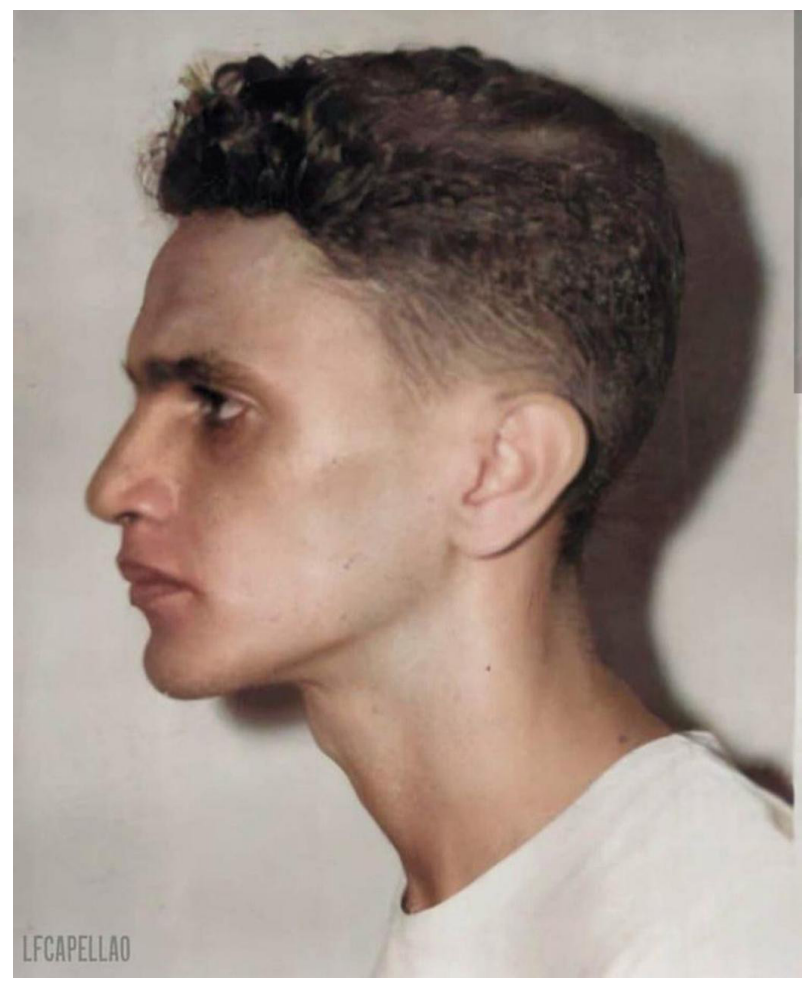

Fonte: Instagram de Caetano Veloso ${ }^{17}$ 
ANEXO II - Documento com letra da canção Alegria, alegria e que compõe o dossiê do cantor, que foi preso pela ditadura militar

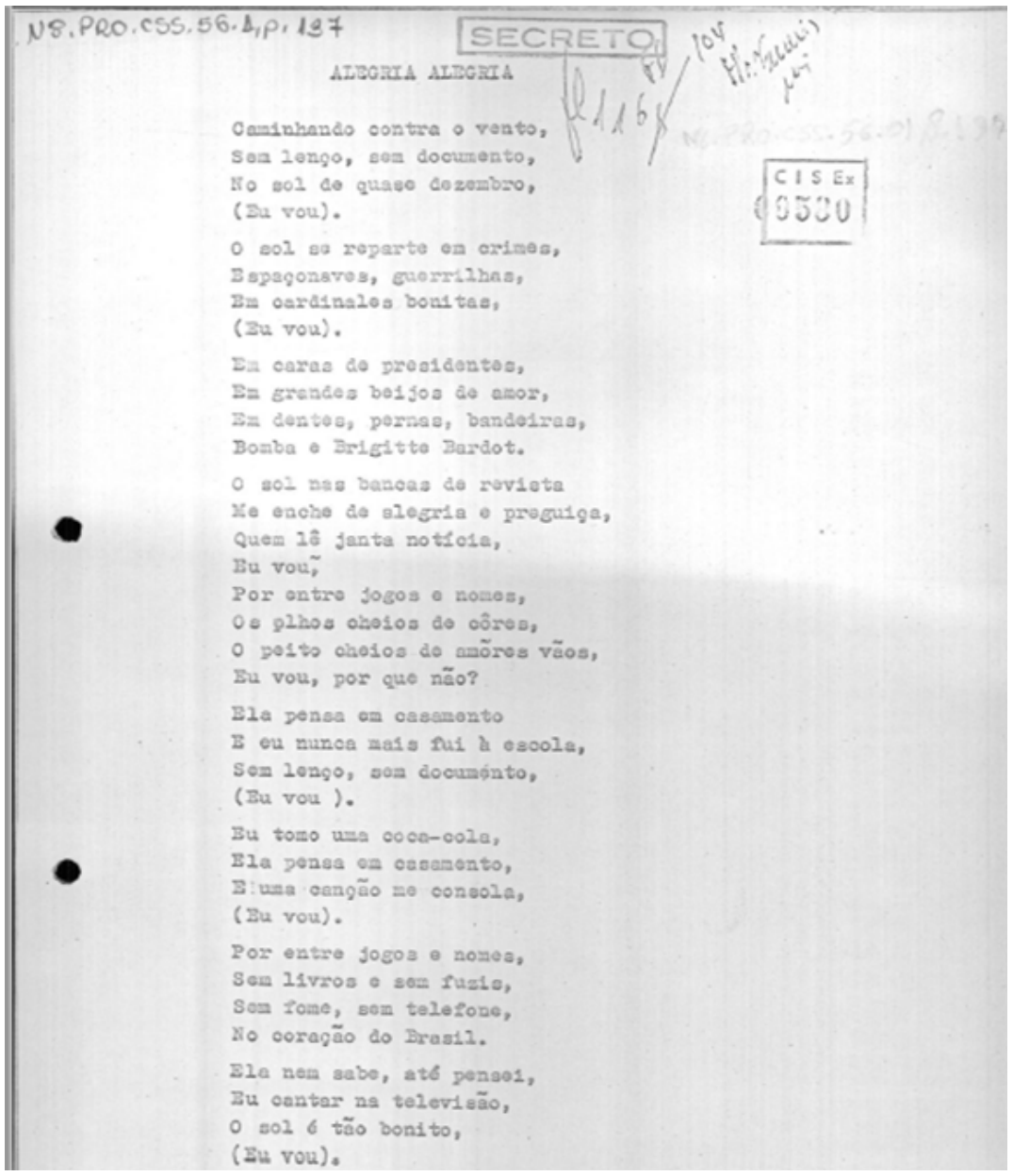

Fonte: ARQUIVO NACIONAL, FUNDO. Conselho de Segurança Nacional, notação br_dfanbsb_n8_0_pro_css_0313_d0001de0001. 1968 
"Alegria, alegria" e "Baby": as canções síntese do movimento tropicalista

ANEXO III - Trecho da canção Baby no dossiê elaborado pelos militares para reunir provas contra Caetano Veloso à época da ditadura militar no Brasil

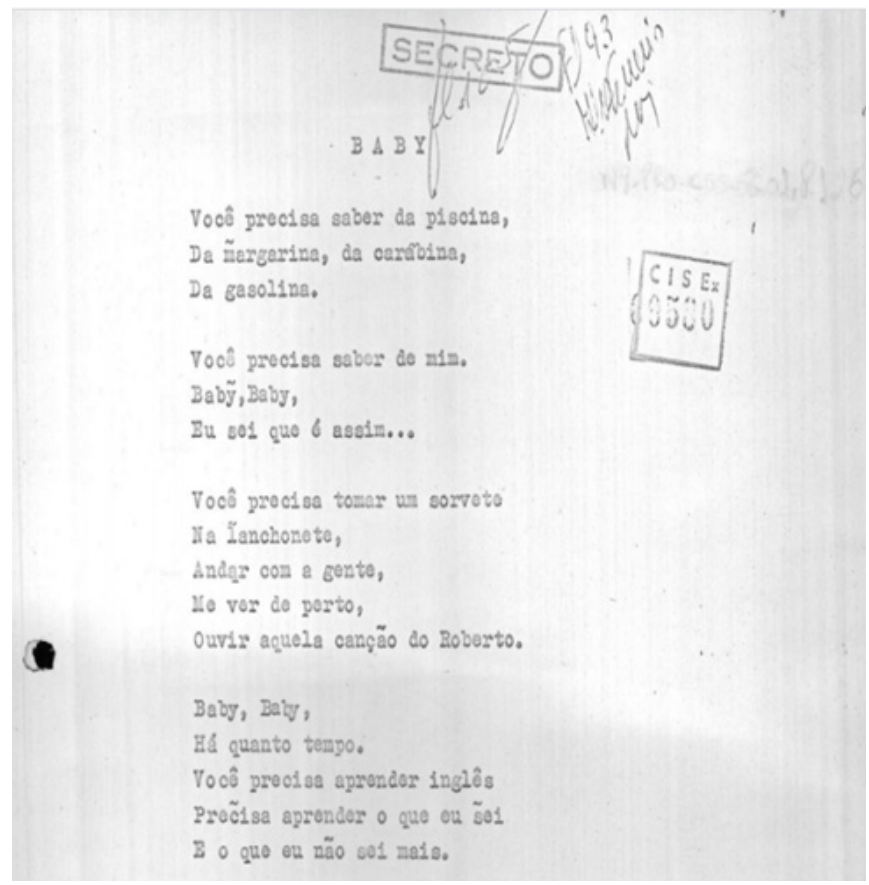

Fonte: ARQUIVO NACIONAL, FUNDO. Conselho de Segurança Nacional, notação br_dfanbsb_n8_0_pro_css_0313_d0001de0001. 1968

\section{ANEXO IV - CANÇÕES CITADAS AO LONGO DESTE TRABALHO}

"Alegria, alegria": https://www.youtube.com/watch?v=he_ghOAXbSM

“Baby”, em clipe de 2019: https://www.youtube.com/watch?v=KMTA5vxsssg "BABY", na gravação original: https://www.youtube.com/watch?v=1XSQwHJLT48 "Irene": https://www.youtube.com/watch?v=INA4Tc0qVcE

"Língua": https://www.youtube.com/watch?v=tX7cqBreLUY

"Terra": https://www.youtube.com/watch?v=WyxL_lbo4kM 